\title{
HUBUNGAN BERAT BADAN BAYI BARU LAHIR DENGAN KEJADIAN RUPTUR PERINEUM PERSALINAN NORMAL PADA IBU PRIMIGRAVIDA
}

\section{The Correlation between Birth Weight and Occurrence of Rupture Perineum in Normal Labour of Primigravida Mothers}

\author{
Heny Noor Wijayanti \\ ${ }^{*}$ Prodi D III Kebidanan Fakultas Ilmu Kesehatan Universitas Respati Yogyakarta \\ E-mail :bie_heny@ymail.com
}

\begin{abstract}
ABSTRAK
Latar Belakang: Angka kematian ibu di Indonesia kembali meningkat menjadi 359 per 100.000 kelahiran hidup. Robekan jalan lahir merupakan penyebab kedua perdarahan setelah atonia uteri. Angka kematian ibu melahirkan di Kabupaten Kendal menduduki peringkat delapan tertinggi di Jawa Tengah dimana pada tahun 2013 sebanyak 21 orang, tahun 2014 turun menjadi 19 orang, namun di tahun 2015 kembali naik menjadi 23 orang. Penelitian ini bertujuan untuk mengetahui hubungan berat badan bayi baru lahir dengan kejadian ruptur perineum persalinan normal pada ibu pimigravida di Puskesmas Gemuh 01 Kecamatan Gemuh Kabupaten Kendal.

Metode: Penelitian kuantitatif dengan metode cross sectional. Populasi adalah seluruh ibu bersalin primigravida di Puskesmas Gemuh 01. Sampel diambil dengan teknik accidental sampling yang berjumlah $34 \mathrm{ibu}$ bersalin primigravida. Analisis data menggunakan uji chisquare.

Hasil: Hasil uji statistik menunjukkan hubungan yang bermakna antara berat badan bayi baru lahir dengan kejadian ruptur perineum persalinan normal pada ibu primigravida dengan nilai $\mathrm{p}=0.021$.

Kesimpulan: Ada hubungan yang signifikan antara berat badan bayi baru lahir dengan kejadian ruptur perineum persalinan normal pada ibu primigravida di Puskesmas Gemuh 01 Kecamatan Gemuh Kabupaten Kendal. Perlu adanya peningkatan pengetahuan dan pengalaman bidan dalam memberikan asuhan kebidanan kepada ibu bersalin sehingga dapat mengenali tanda-tanda perineum kaku saat persalinan berlangsung serta dapat menilai dan mengambil tindakan yang tepat untuk menghindari terjadinya ruptur perineum.
\end{abstract}

Kata kunci: Berat Badan Bayi Baru Lahir, Ruptur Perineum, Persalinan 


\section{ABSTRACT}

Background: Maternal Mortality Rate (MMR) is still quite high at 359 per 100,000 live births. Ruptured perineum is the second leading cause of bleeding after uterine atony. The maternal mortality rate in Kendal Regency was ranked the eighth highest in Central Java where in 2013 there were 21 people, in 2014 it fell to 19 people, but in 2015 it rose to 23 people. This study aimed to know the correlation between birth weight and rupture perineum occurrence in normal labor of primigravida mother at Gemuh 01 Local Government Clinic Gemuh Sub District Kendal Regency.

Method: The research was quantitative research with cross sectional method. A sample of 34 primigravida mothers from Gemuh 01 Local Government Clinic was selected by accidental sampling method. The data were analyzed by a chi-square test.

Results: Statistical analysis showed a significant correlation between birth weight with the occurrence of rupture perineum on primigravida mother with $p$ value $=0.001$.

Conclusion: There is a significant relationship between birth weight and occurrence of rupture perineum in primigravida mothers at Gemuh 01 Local Government Clinic Gemuh Sub District Kendal Regency. This requires increased knowledge and experience of midwives in providing midwifery care to delivery mothers so that they can recognize the signs of a rigid perineum during labour as well as to assess and take appropriate action to avoid the occurrence of perineal rupture.

Keywords: Birth Weight, Ruptured Perineum, Labour

\section{PENDAHULUAN}

Angka Kematian Ibu (AKI) dan Angka Kematian Bayi (AKB) merupakan salah satu indikator pembangunan kesehatan dalam RPJMN 2015-2019 dan SDGs yaitu menjamin kehidupan yang sehat dan mendorong kesejahteraan bagi semua orang di segala usia pada tahun 2030 dengan salah satu targetnya adalah mengurangi AKI hingga di bawah 70/100.000 kelahiran hidup. Menurut data SDKI, Angka Kematian Ibu sudah mengalami penurunan pada periode tahun 1994-2012 yaitu pada tahun 1994 sebesar 390/100.000 kelahiran hidup, tahun 1997 sebesar 334/100.000 kelahiran hidup, tahun 2002 sebesar 307/100.000 kelahiran hidup, tahun 2007 sebesar 228/100.000 kelahiran hidup, namun pada tahun 2012 AKI kembali meningkat menjadi 359/100.000 kelahiran hidup ${ }^{(1)}$.

Tiga faktor utama kematian ibu melahirkan adalah perdarahan (28\%), eklampsia (24\%), dan infeksi (11\%). Diperkirakan terdapat 14 juta kasus perdarahan dalam kehamilan di Indonesia. Setiap tahunnya paling sedikit 128.000 pe- rempuan mengalami perdarahan sampai meninggal. Perdarahan pasca persalinan terutama perdarahan postpartum primer merupakan perdarahan yang paling banyak menyebabkan kematian $\mathrm{ibu}^{(2)}$.

Penyebab tertinggi perdarahan postpartum adalah atonia uteri (50-60\%), retensio plasenta (16-17\%), retensio sisa plasenta (23-24\%), laserasi jalan lahir (4-5\%), dan kelainan darah (0.5-0.8\%). Perdarahan pasca persalinan juga seringkali disebabkan oleh robekan perineum. Robekan perineum biasanya ringan, tetapi kadang-kadang terjadi juga luka yang luas dan berbahaya. Penyebab utama kematian ibu di Indonesia adalah perdarahan postpartum karena atonia uteri, sedangkan laserasi jalan lahir menjadi penyebab kedua yang salah satunya adalah ruptur perineum yang dapat terjadi pada hampir setiap persalinan pervaginam ${ }^{(3)}$.

Perdarahan postpartum merupakan bagian terbanyak dari perdarahan obstetrik sebagai penyebab kematian maternal. Secara medis penyebab perdarahan postpartum disebabkan oleh faktor 4T, yakni tonus (atonia uteri), trauma (robe- 
kan jalan lahir), tissue (retensi plasenta atau sisa plasenta) dan trombin (kelainan koagulasi darah). Kegagalan penanganan perdarahan obstetrik dipengaruhi oleh beberapa faktor keterlambatan, baik keterlambatan pengenalan adanya perdarahan, intensitas perdarahan, keterlambatan transportasi, dan keterlambatan dalam penanganan. Keterlambatan rujukan meningkatkan kematian maternal sebanyak 5.27 kali dan keterlambatan penanganan di rumah sakit 12.73 kali. Perdarahan lebih dari $1500 \mathrm{ml}$ menaikkan kematian maternal sebanyak $4.18 \mathrm{kali}^{(4)}$.

Laserasi jalan lahir merupakan penyebab kedua perdarahan setelah atonia uteri yang terjadi pada hampir persalinan pertama dan tidak jarang juga pada persalinan berikutnya. Pada seorang primipara atau orang yang baru pertama kali melahirkan, ketika terjadi peristiwa "kepala keluar pintu" biasanya tidak dapat tegangan yang kuat sehingga robek pada pinggir depannya. Luka-luka biasanya ringan tetapi kadang-kadang terjadi juga luka yang luas dan berbahaya. Sebagai akibat persalinan terutama pada seorang primipara, biasa timbul luka pada vulva di sekitar introitus vagina yang biasanya tidak dalam akan tetapi kadang-kadang bisa timbul perdarahan banyak ${ }^{(5)}$.

Berat badan bayi dapat mempengaruhi proses persalinan kala II. Berat badan bayi lahir umumnya antara 25004000 gramam $^{(6)}$. Semakin besar bayi yang dilahirkan akan meningkatkan resiko terjadinya ruptur perineum. Sedangkan dilihat dari status paritas umumnya ruptur perineum terjadi pada primipara, tetapi tidak jarang juga terjadi pada multipara. Penyebab yang biasa terjadi pada ibu adalah partus presipitatus, mengejan terlalu kuat, edema, kerapuhan pada perineum, kelenturan jalan lahir, dan persalinan dengan tindakan ${ }^{(7)}$.

Angka kematian ibu melahirkan di Kabupaten Kendal tergolong tinggi, yaitu nomor delapan tertinggi di Jawa
Tengah. Sesuai data dari Dinas Kesehatan Kabupaten Kendal, jumlah kematian ibu melahirkan di tahun 2013 sebanyak 21 orang, tahun 2014 turun menjadi 19 orang, namun di tahun 2015 kembali naik menjadi 23 orang $^{(8)}$. Kejadian ruptur perineum di Puskesmas Gemuh 01 selama bulan Januari-Oktober 2010 mayoritas terjadi pada bayi dengan berat badan lahir normal (>2500-4000 g) yaitu sebesar $77.77 \%$. Selain itu terjadi 2 kematian ibu bersalin. Kematian 2 ibu bersalin tersebut dikarenakan perdarahan postpartum.

Tujuan penelitian ini adalah untuk mengetahui hubungan berat badan bayi baru lahir dengan kejadian ruptur perineum persalinan normal pada ibu primigravida di Puskesmas Gemuh 01 Kecamatan Gemuh Kabupaten Kendal.

\section{SUBJEK DAN METODE}

Penelitian ini menggunakan metode penelitian deskriptif korelasi dengan pendekatan studi cross sectional. Populasi dalam penelitian ini adalah seluruh ibu bersalin primigravida. Pengambilan sampel menggunakan teknik accidental sampling dimana didapatkan sejumlah $34 \mathrm{ibu}$ bersalin primigravida.

Instrumen penelitian ini menggunakan master tabel. Pengumpulan data menggunakan lembar observasi yang meliputi data tentang berat bayi baru lahir dan kejadian ruptur perineum. Analisis data dilakukan dengan dua cara yaitu analisis univariat dan analisis bivariat dengan uji chi square.

\section{HASIL}

\section{Karakteristik Responden}

Berdasarkan tabel 1 diperoleh hasil bahwa seluruh responden penelitian berumur usia reproduksi sehat (20-35 tahun). Sebagian besar responden penelitian berpendidikan SMP yaitu sebanyak 15 responden $(44,1 \%)$, sedangkan 5 responden (14.7\%) berpendidikan SD dan 14 respo- 
nden $(41.2 \%)$ berpendidikan SMA. Seluruh responden penelitian tidak bekerja.

\section{Analisis Univariat}

Berdasarkan tabel 2 diperoleh hasil bahwa distribusi frekuensi responden penelitian berdasarkan berat badan lahir bayi yaitu bayi dengan berat badan lahir $<2500$ gram sebanyak 4 responden (11.8\%), 2500-4000 gramam yaitu sebanyak 29 responden $(85.3 \%)$, dan $>4000$ gram sebanyak 1 responden $(2.9 \%)$. Distribusi frekuensi responden penelitian berdasarkan kejadian ruptur perineum yaitu sebanyak 21 responden $(61.8 \%)$ mengalami ruptur perineum sedangkan 13 responden $(38.2 \%)$ tidak mengalami ruptur perineum.

\section{Analisis Bivariat}

Tabel 3 menunjukkan bahwa berdasarkan hasil analisis hubungan antara berat badan bayi baru lahir dengan kejadian ruptur perineum persalinan normal pada ibu primigravida diperoleh bahwa sebanyak $20(58.82 \%)$ ibu mengalami ruptur perineum dengan berat badan bayi baru lahir 2500-4000 gramam dan 1 (2.94\%) ibu mengalami ruptur perineum dengan berat badan bayi baru lahir $>4000$ gram .

Hasil uji statistik chi-square diperoleh nilai $\mathrm{p}=0.021$ sehingga dapat disimpulkan bahwa terdapat perbedaan proporsi kejadian ruptur perineum antara berat badan bayi baru lahir 2500-4000 gram dengan $>4000$ gram. Terdapat hubungan yang signifikan antara berat badan bayi baru lahir dengan kejadian ruptur perineum persalinan normal pada ibu primigravida.

Tabel 1. Karakteristik Responden

\begin{tabular}{lcc}
\hline \multicolumn{1}{c}{ Karakteristik } & Frekuensi & $\%$ \\
\hline Umur & & \\
$<20$ & 0 & 0 \\
$20-35$ & 34 & 100 \\
$>35$ & 0 & 0 \\
Pendidikan & & \\
SD & 5 & 14.7 \\
SMP & 15 & 44.1 \\
SMA & 14 & 41.2 \\
Pekerjaan & & \\
Bekerja & 0 & 0 \\
Tidak Bekerja & 34 & 100 \\
$\quad$ Jumlah & 34 & 100 \\
\hline Sum: Data & &
\end{tabular}

Sumber: Data primer

Tabel 2. Distribusi Frekuensi Berat Badan Bayi Baru Lahir dan Kejadian Ruptur Perineum di Puskesmas Gemuh 01 Kecamatan Gemuh Kabupaten Kendal.

\begin{tabular}{lcc}
\hline \multicolumn{1}{c}{ Variabel } & Frekuensi & $\%$ \\
\hline $\begin{array}{l}\text { Berat Badan } \\
\text { Lahir Bayi } \\
<2500\end{array}$ & & \\
$2500-4000$ & 29 & 11.8 \\
$>4000$ & 1 & 2.9 \\
Kejadian & & \\
$\begin{array}{l}\text { Ruptur } \\
\text { Perineum }\end{array}$ & & \\
$\begin{array}{l}\text { Ruptur } \\
\text { Perineum } \\
\text { Tidak Ruptur }\end{array}$ & 21 & 61.8 \\
Perineum & 13 & 38.2 \\
\hline \multicolumn{1}{c}{ Jumlah } & 34 & 100 \\
\hline
\end{tabular}

Sumber: Data primer 
Tabel 3. Analisis Hubungan Berat Badan Bayi Baru Lahir dengan Kejadian Ruptur Perineum Persalinan Normal Pada Ibu Primigravida di Puskesmas Gemuh 01 Kecamatan Gemuh Kabupaten Kendal.

\begin{tabular}{|c|c|c|c|c|c|c|c|}
\hline \multirow{4}{*}{$\begin{array}{c}\text { Berat Badan } \\
\text { Bayi Baru } \\
\text { Lahir }\end{array}$} & \multicolumn{4}{|c|}{ Kejadian Ruptur Perineum } & \multirow{3}{*}{\multicolumn{2}{|c|}{ Total }} & \multirow{4}{*}{$\mathbf{P}$} \\
\hline & \multirow{2}{*}{\multicolumn{2}{|c|}{$\begin{array}{c}\text { Ruptur } \\
\text { Perineum }\end{array}$}} & \multirow{2}{*}{\multicolumn{2}{|c|}{$\begin{array}{l}\text { Tidak Ruptur } \\
\text { Perineum }\end{array}$}} & & & \\
\hline & & & & & & & \\
\hline & $\mathbf{F}$ & $\%$ & $\mathbf{F}$ & $\%$ & $\mathbf{F}$ & $\%$ & \\
\hline$<2500 \mathrm{gr}$ & 0 & 0 & 4 & 11.77 & 4 & 11.77 & \\
\hline $2500-4000 \mathrm{gr}$ & 20 & 58.82 & 9 & 26.47 & 29 & 85.29 & 0,021 \\
\hline$>4000 \mathrm{gr}$ & 1 & 2.94 & 0 & 0 & 1 & 2.94 & \\
\hline Total & 21 & 61.76 & 13 & 38.24 & 34 & 100 & \\
\hline
\end{tabular}

Sumber: Data primer

\section{PEMBAHASAN}

Berdasarkan hasil penelitian tentang hubungan berat badan bayi baru lahir dengan kejadian ruptur perineum persalinan normal pada ibu primigravida di Puskesmas Gemuh 01 diperoleh data 34 kasus persalinan. Dari data 34 kasus persalinan hasil analisis data yang diperoleh sebagian besar responden melahirkan bayinya dengan berat badan bayi baru lahir yaitu 2500-4000 gram sebanyak 29 responden $(85.3 \%)$. Hal ini menunjukkan bahwa secara keseluruhan berat badan bayi yang lahir rata-rata berat badannya normal.

Sejalan dengan ${ }^{(6)}$ yang menyatakan bahwa berat badan bayi lahir normal antara 2500-4000 gram, didapatkan dari hasil penimbangan 24 jam pertama kelahiran. Sedangkan berat badan bayi baru lahir dapat mempengaruhi proses persalinan kala II, semakin besar bayi yang dilahirkan akan meningkatkan resiko terjadinya ruptur perineum. Bayi besar adalah bayi dengan berat badan lahir lebih dari 4000 gram.

Sebagian besar responden yang mengalami ruptur perineum dikarenakan berat badan bayi baru lahir, perineum ka$\mathrm{ku}$, kepala janin terlalu cepat melewati dasar panggul dan cara meneran yang salah. Hasil penelitian mendapatkan jumlah ibu bersalin primigravida dengan kejadian ruptur perineum sebanyak 21 responden $(61,8 \%)$ dari seluruh persalinan.
Hal ini menunjukkan bahwa ibu bersalin primigravida yang perineumnya kaku, melahirkan bayi dengan berat badan bayi yang cukup besar, kepala janin terlalu cepat melewati dasar panggul sehingga mudah sekali untuk terjadi ruptur perineum.

Ibu primipara atau ibu yang baru pertama kali melahirkan ketika terjadi peristiwa "kepala keluar pintu" biasanya tidak terdapat tegangan yang kuat sehingga robek pada pinggir depannya. Luka-luka biasanya ringan tetapi kadangkadang terjadi juga luka yang luas dan berbahaya. Sebagai akibat persalinan terutama pada seorang primipara, biasa timbul luka pada vulva di sekitar introitus vagina yang biasanya tidak dalam akan tetapi kadang-kadang bisa timbul perdarahan banyak $^{(5)}$.

Ruptur perineum dialami oleh $85 \%$ wanita yang melahirkan pervaginam. Ruptur perineum perlu mendapatkan perhatian karena dapat menyebabkan disfungsi organ reproduksi wanita, sebagai sumber perdarahan atau jalan keluar masuknya infeksi, yang kemudian dapat menyebabkan kematian karena perdarahan atau sepsis ${ }^{(9)}$. Resiko komplikasi yang mungkin terjadi jika ruptur perineum tidak segera diatasi, yaitu perdarahan, fistula, hematoma, infeksi ${ }^{(10)}$. Dengan demikian ibu bersalin primigravida cenderung mengalami ruptur saat persalinan yang disebabkan karena pada pri- 
migravida perineumnya masih kaku di mana perineum yang kaku menghambat persalinan kala II yang meningkatkan risiko kematian bagi janin dan menyebabkan kerusakan jalan lahir yang luas.

Berdasarkan data yang diperoleh dari penelitian ini menunjukkan bahwa terdapat 21 kasus kejadian ruptur perineum. Persentase ibu bersalin yang mengalami ruptur perineum berdasarkan berat bayi baru lahir sebagian besar terjadi pada bayi dengan berat 2500-4000 gram yaitu sebanyak 20 responden $(58.82 \%)$, sedangkan bayi dengan berat badan lahir $>4000$ gram, terdapat $1(2.94 \%) \mathrm{ibu}$ yang mengalami kejadian ruptur perineum. Hasil uji statistik diperoleh nilai $\mathrm{p}=$ 0.021 sehingga dapat disimpulkan terdapat perbedaan proporsi kejadian ruptur perineum antara bayi yang berat badan bayi baru lahir 2500-4000 gram dengan $>4000$ gram (terdapat hubungan yang signifikan antara berat badan bayi baru lahir dengan kejadian ruptur perineum persalinan normal pada ibu primigravida).

Ibu bersalin primigravida yang melahirkan bayi dengan berat badan 25004000 gram memiliki risiko lebih tinggi terhadap kejadian ruptur perineum dibandingkan dengan bayi dengan berat badan lahir <2500 gram. Faktor perineum ibu yang kaku, kepala janin yang cepat melewati dasar panggul, dan cara meneran yang salah juga meningkatkan risiko kejadian ruptur perineum. Persalinan normal bisa mengakibatkan terjadinya kasus ruptur perineum pada ibu primipara maupun multipara. Lapisan mukosa dan kulit perineum pada seorang ibu primipara mudah terjadi ruptur yang bisa menimbulkan perdarahan pervaginam ${ }^{(11)}$.

Hasil Penelitian ini menunjukan bahwa terdapat hubungan antara berat lahir bayi dengan kejadian ruptur perineum, dimana semakin besar berat lahir bayi semakin tinggi tingkat ruptur perineum pada ibu primipara. Hal ini sesuai dengan pendapat ${ }^{(12)}$ yang menyatakan bahwa ruptur perineum disebabkan oleh berat lahir bayi yang besar. Semakin besar berat badan bayi yang dilahirkan akan meningkatkan resiko terjadinya ruptur perineum, karena perineum tidak cukup kuat menahan regangan kepala bayi dengan berat badan bayi yang besar, sehingga pada proses kelahiran bayi dengan berat badan bayi lahir yang besar sering terjadi ruptur perineum.

Sejalan dengan ${ }^{(6)}$ yang menyatakan berat badan bayi lahir normal antara 2500-4000 gram, didapatkan dari hasil penimbangan 24 jam pertama kelahiran. Berat badan lahir bayi dapat mempengaruhi proses persalinan kala II, semakin besar bayi yang dilahirkan akan meningkatkan resiko terjadinya ruptur perineum. Bayi besar adalah bayi yang begitu lahir memiliki bobot lebih dari 4000 gram.

Sejalan dengan teori ${ }^{(13)}$ yang menyatakan bahwa umumnya ruptur perineum terjadi pada primipara, tetapi tidak jarang juga pada multipara. Ruptur perineum biasa terjadi pada keadaan partus presipitatus, mengejan terlalu kuat, edema dan kerapuhan pada perineum, kelenturan jalan lahir, serta persalinan dengan tindakan. Apabila dilihat dari faktor risikonya, ibu bersalin primipara memiliki risiko mengalami ruptur perineum lebih tinggi dibandingkan dengan ibu bersalin multipara, tergantung bagaimana penolong melakukan pertolongan persalinan dan asuhan sayang ibu pada saat proses persalinan.

Sesuai dengan keadaan di atas dapat digambarkan bahwa berat badan bayi baru lahir sangat berpengaruh terhadap kejadian ruptur perineum sehingga harus dilakukan deteksi dini dengan cara melakukan pemantauan berat badan janin rutin pada saat kehamilan antara lain dengan cara mengontrol pola makan ibu yang sehat dan seimbang serta melakukan pengukuran tinggi fundus uteri untuk 
menentukan taksiran berat janin secara cermat pada setiap pemeriksaan.

\section{SIMPULAN DAN SARAN}

\section{Simpulan}

1. Berat badan bayi baru lahir di Puskesmas Gemuh 01 Kecamatan Gemuh Kabupaten Kendal bayi sebagian 2500-4000 gram.

2. Sebagian besar ibu bersalin primigravida di Puskesmas Gemuh 01 Kecamatan Gemuh Kabupaten Kendal mengalami kejadian ruptur perineum.

3. Ada hubungan yang signifikan antara berat badan bayi baru lahir dengan kejadian ruptur perineum persalinan normal pada ibu primigravida di Puskesmas Gemuh 01 Kecamatan Gemuh Kabupaten Kendal.

\section{Saran}

Perlu peningkatan pemahaman dan pengetahuan bagi ibu primigravida agar lebih waspada terhadap kejadian ruptur perineum karena semakin besar taksiran berat janin yang akan dilahirkan maka risiko ruptur juga semakin besar. Namun hal ini dapat dikurangi risikonya dengan pemeriksaan kehamilan yang rutin dan penanganan persalinan oleh tenaga kesehatan.

\section{DAFTAR PUSTAKA}

1. SDKI (2012). Survey Demografi Kesehatan Indonesia. Jakarta.

2. Kementerian Kesehatan Republik Indonesia (2010). Survey Demografi Kesehatan Indonesia. Jakarta.
3. Sumarah dkk (2009). Perawatan ibu bersalin. Yogyakarta: Penerbit CV Fitramaya. Cet 1.

4. Siswosudarmo (2009). Obstetri Fisiologi. Yogyakarta: Bidang Diklat RSUP DR. Sardjito.

5. Prawirohardjo S (2008). Ilmu Kandungan. Jakarta: Yayasan Bina Pustaka Sarwono Prawirohardjo.

6. Vivian (2011). Asuhan Neonatus Bayi dan Anak Balita. Jakarta: Penerbit PT Selemba Medika.

7. William (2010). Ilmu Kebidanan Patologi dan Fisiologi Kebidanan. Yogyakarta: Penerbit C.V Andi Offset.

8. Dinas Kesehatan Kabupaten Kendal (2015). Profil Kesehatan Kabupaten Kendal. Kendal.

9. Chapman V (2013). Persalinan dan Kelahiran Asuh Kebidanan. Jakarta: EGC

10. Rosdiana (2013). Faktor-Faktor yang Mempengaruhi Terjadinya Ruptur Perineum pada Ibu Bersalin Normal.

Stmikubudiyah.http://simtakp.stmik ubudiyah.ac.id/docjurnal/ROSDIA

NAjurnal_div_kebidanan. pdf. 27 Februari 2014.

11. Wiknjosastro H (2008). Ilmu Kandungan. Jakarta : Yayasan Bina Pustaka Sarwono Prawirohardjo.

12. Varney H (2008). Buku Ajar Asuhan Kebidanan Vol 2. Jakarta: EGC.

13. Oxorn, Harry, Forte WR (2010). Ilmu Kebidanan Patologi dan Fisiologi Persalinan. Yogyakarta: Yayasan Essentia Medica. 